\title{
9-11 Year Old Students' Perception of Violence Reflected in Their Drawings
}

\author{
Melih Burak Ozdemir \\ Research Center of Counselling, Samsun,Turkey \\ Senem Gurkan \\ Ondokuz Mayıs University, Samsun,Turkey \\ Yashar Barut \\ Ondokuz Mayıs University, Samsun,Turkey
}

\section{Introduction}

Violence is a universal phenomenon that deeply influences society and gives harm that is not easy to fix today. A child, who witnessed violence, even if $s /$ he is not directly exposed to it, regards violence as a way of solving problems. If we think that the World live in peace when there is no war, we are wrong. If our women and young girls are exposed to each and every type of violence fluently at home, in the streets, at school and at work, this means that the war is going on and is to be stopped (Page and İnce, 2008). The societies that see violence as natural and that have not completed their stages of humanity and civilization are regarded as uncivilized (Şenol and Mazman, 2014). Sociologists state that the violence phenomenon can be best dealt within the dynamics of social relationships with an integrated approach. As the conflicts mostly occur between the individuals or groups which are in relationship between each other (Kocac1k, 2001). Whether individual or social, violence as a behavior is said to have similar patterns with primitive societies and children (Güleç, Topaloğlu, Ünsal and Altıntaş, 2012).

Violence is the use of strength with an aggressive tendency in a harmful manner to an individual, a group or more general, to a society (Ayan, 2007). As an industrializing city community we apply some small violence types every day. For instance giving effort to get the forefront in the bus queue or while pushing one's shoulder at the time the doors of a port are opened are seem to be as little dance shows, but are the violence applications whose dense are low (Mülayim, 2000). The fact that which behaviors are regarded as violence is related with the structural 
features of that society, that is, about the cultural structure valid for value judgments (Kocac1k, 2001).

Violence is a universal phenomenon that is present in every walk of a human's life. Its universality stems from its harmful quality to individuals and the society (Ayan, 2006).

From a narrow perspective, violence identifies physical violence. Physical violence, on the other hand, is an extrinsic, hard and painful action to people's physical integrity. From a broad perspective, violence can be psychological, the psychological and physical influences of which cannot be measured and which can be felt indirectly (Meb, 2008).

Violence is one of the front running factors effecting the physical and emotional developments of children (Deveci, Karadağ and Y1lmaz, 2008). According to the researches, the most important factors effecting violence can be classified into three groups: first is the family and the environment, second is the level of education and third, perhaps the most important of all, is the media. There is no doubt that these institutions and tools having important influences in personality development play a significant role in the development of attitudes and behaviors regarding violence and world views (Ayan, 2006).

It must not be forgotten that the physical penalties in the family, at school or in other environments will stimulate the child's violence behavior in his future life (Çubukçu ve Dönmez, 2012).

If the children are born in a family where domestic violence occurs, these children are tends to have some psychological problems such as being the user of the violence or being exposed to violence (İbilioğlu, 2012). In their research on the drawings about the theme violence, Hiçyılmaz, İnci ve Seven (2015) showed that the dominant social power in the drawings is media and houses and streets are the places that are regarded as the places of violence. Other researches also reveal that the people, especially the children and young people who spend time with media products that include violence, internalize violence. However, most dangerous of all, as media teaches violence to society, the society becomes more and more insensible to violence (Zorlu, 2016).

\section{Drawing in Psychology}

Drawing in psychology was firstly dealt by Binet in 1890 from the perspective of merely mental development and mental problems and away from artistic aspects such as depth, fiction and color. In the publication called "The Comment on 
Drawings", the psychological aspect of drawing was studied. After Alfred Binet, many drawings, but especially children drawings were handled from a psychological perspective by the psychologists (Arıc1, 2006). When it is considered that the first human being left some traces on the walls of the caves, drawings are one of the tools for expression of the communication and interaction between the individuals such as words and letters. The interest in children drawings, different from that of adult drawings, has attracted the attentions of the people who were interested in arts, especially psychologists and educators after 19th century and so on (Yildiz, 2012).

The founders of the modern arts, Freud and Jung, studied the mutual connection between arts, symbol and personalities. Freud observed that images represent the forgotten or repressed memories and these symbols may arise through dreams and drawings. Freud also believed that the universal human conflicts and neurosis directs the artists via arts. This observation firstly made the people believe, then corrected that expressing with drawing is the way that goes to the understanding of the inner World of human spirit. Nitsch, on the other hand, performed hundreds of shows similar to the bloody rituals of the past, by the animals he killed and the organs and blood until 70 s to today. Within these performances, struggling between bloods, dancing, making love and drinking blood were ordinary things. Nitsch, who believed that the instinction of repressed attraction in human needs to be expressed in some way Antmen (2009) (transf.Y1lmaz, 2013); so Katharsis will occur.

\section{Drawing and Children}

A human being is a social living thing. S/he lives in a social environment and s/he affects the environment, and also is affected by the environment. Any of the scientific study that does not evaluate a person without his environment cannot be adequate to understand and express human. In that case, the drawings will be affected both by his ability and his social environment (Keskin Paktuna, 2010). Making the children draw is an ideal method for exploring the inner world of a child (Durualp, Çiçenoğlu, Mümünoğlu, Kalkanlı, ve Altuntaş, 2012). It is the view of the most natural images that a child produces emotionally and intellectually. This feature, that is the reflection of the general development and inner world of a child, resembles to the emotional period of the works of the famous artists (Artut, 2004).

The drawings of the children are the indicators of the relationship between the children and their objective World and the action that the children tries to change this World. These drawings help us recognize the child from a psycho-pedagogical 
perspective as these are the results of the psychological necessities. A child can express the emotions, thoughts and necessities by drawings easier than expressing them verbally (Savaş, 2014).

Hiçyllmaz and others (2015) studied how the children perceive themselves and World with the drawings they drew. In their research, Kar ve Toros (2015) revealed that the children who witness domestic violence in their families reflect this violence to their drawings. The member of the family who are seen as the cause of this situation was portrayed in a bad condition, or a girl who was exposed to violence by her dad, portrayed her father in an aggressive manner and with sharp teeth.

It is beyond doubt a mistake to evaluate, generalize and think the samples as models of a child by merely looking at their drawings (Yavuzer, 2009, 5). The drawings not only tell us the child's way of thinking, but also they give us some clues about their problems with adults and other children (Yavuzer, 2009, 11).

As the verbal approaches are finite today, some other methods such as drawing, play, etc. are used. The experts of this field use drawing mostly. A child can draw whatever s/he wants freely which shows that they reflect their inner world to us directly.

\section{Art and Violence}

Art is an effective and successful way of expressing emotions and thoughts. Because art has structures that can bypass the conscious censor that mind applies to words and reveals the emotions and experiences hidden in depth (Kar ve Toros, 2015). What we call art is a production of the behaviors. And what we call behavior is related to psychology (Gürsu, 2015). Some of the philosophers of the beginning of the last century are of the opinion that art need to be the basis of the psychology Acar (2015) (trans. Kar ve Toros, 2015).

Violence has been reflected to some Works of art in different purposes and forms within the history of arts. For instance music, known as "healing the soul", is full of themes reflecting the tragedies of humanity such as war, poverty, death (Ötgün, 2008).

In the past, the kingdoms, empires and states used their violent scenes to threaten their enemies, to show their power and conquest. Many societies built bridges and castles (such as the Great Wall of China) to protect themselves from violence in the past. The massive and plastic structure in these instances is the symbolic forms showing the dimensions of the tension between people (Ötgün, 2008). Art has been 
the reflection of the noble and supreme emotions such as love, peace, friendship, sympathy, etc. together with the passions such as hatred, jealousy and the need for gaining more (Mülayim, 2000).

\section{Aim of the Study}

The aim of this study is to achieve children's perception of violence expressed by drawing and obtaining data this way. Within this context, these questions were tried to be replied:

1. What type of violence is illustrated in the drawings of the children?

2. How are the personal features of the violent people or violent victims portrayed?

3 . How are the types of violence portrayed?

\section{Limitations}

The sample of this research, conducted in Samsun province Çarşamba district in 2015-2016 fall education season, is limited with the drawings of the students of 911 ages.

\section{Methodology}

\section{Research Model}

This qualitative study examines the perceptions of violence of the drawings of 9-11 year-old students. As a method, scanning method was used and it was aimed to achieve children's perception of violence expressed by drawing.

\section{Participants}

In qualitative research method, to include many individuals in number is hard because the data obtained need to be detailed and deep. The number of the participants of the study is low, but the data obtained and the details of the data are many in number and in detail (Yıldırım ve Şimşek, 2013).

In this study, firstly the list of the primary schools from middle socio-economic class in 2015-2016 fall education season were taken from the Directorate of National Education of Çarşamba and two primary schools were chosen randomly. 34 female and 35 male students from 9-11 ages were included in the study. As it is hard to reach all of the 9-11 year-old primary school students in Çarşamba district, the participants of the study were chosen randomly. Totally 69 students from middle socio economic level was chosen as the participants of the study. 
The reason for choosing 9-11 year-old students was that this period is critical for the physical and psychological development of children. Within this period, named as realistic period, the children approach to drawing in a realistic way. There is proportion between the parts of the body in the figures. There are differences between the drawings of the female and male students. Female students draw dolls and clothing while male students draw cars, planes, etc. MEB (2001: 21) (transf. Savaş, 2014). It is observed that a child at this period draws the lines in a more detailed way and he is in a more realistic approach (Ar1c1, 2006). When he is 8 years old, the proportion of the lines is very close to the reality. A spot on the lips or the crew neck of a T-shirt are indispensable. These details are not drawn by looking at the model, but by reflecting the details in the mind on the paper (Keskin Paktuna, 2010).

\section{Data Collection}

In a qualitative study, mostly three kinds of data are collected: Data about the environment, about the period and about the perceptions LeCompte ve Goetz (1984) (transf. Yıldırım ve Şimşek, 2013). The data collection of our research is about collecting the data about the perceptions of children of violence.

Before starting to our research, we introduced ourselves to students and we gave them information about the aim of the study. We also told them that the data will be used in a scientific study and will not be shared with anyone else. Then, in order to determine their perceptions of violence, we wanted them to draw a picture about the user and witness of violence. We told that "Now, I want you to draw a picture about an act of violence that you witnessed or heard before. There will be a person or some people who use violence and who are exposed to violence. After you finish drawing, can you please write your sex, age and the theme of your drawing on the back of the paper?". One of the basic problems in analyzing a drawing is interpreting the drawing in a researching approach Leonard (2006) (transf. Sadık, Çakan ve Artut, 2011). Within this context, the students were asked to write their sex, age and the theme of your drawing on the back of the paper. They had a lesson to finish this activity. Each student had a drawing paper of $30 \times 40 \mathrm{~cm}$ and crayons. They were placed one by one in order not to be affected by each other. They were allowed to draw whatever and in what color they wanted. They were warned that this activity was not an exam, so they did not need to copy from each other.

\section{Evaluation and Analysis of the Data}

The drawings of the children were examined semantically and content analysis method was used. Content analysis is a method used for collecting the similar data within the framework of concepts and themes and organizing these data in a way 
that the readers can understand. Content analysis is not merely used for texts (Yıldırım ve Şimşek, 2013). The basic process within this method is collecting the similar data within the framework of concepts and themes and organizing these data. So the drawings were pre examined firstly in order to see if there is a drawing without a theme. As the research focuses on which elements the children consider for violence, the lines and colors they used were not taken into account.

It was found out that there was more than one theme on one of the papers. Within this study, 53 drawing papers and 65 themes were examined. Each theme was examined separately. Each theme was numbered separately and the themes were dealt respectively. Within content analysis, three themes were specified: violence topics, features of perpetrators and victims, types of violence. The drawings were analyzed within these themes. The comments on the drawings were shown to an expert. The expert hesitated on seven of the drawings if there had been violence on the paper or not. So, a second expert commented on the drawings and at the end eventually they reached to a consensus. In analyzing the drawings, the writings of the children and the comments of the researchers were taken into account. The sex of the children ( $\mathrm{F}$ for females and $\mathrm{M}$ for males) and the ages of the children were noted on the top of the drawings. 16 drawings on which there was no theme and whose themes were not understood were not included into the research. So, the research was done with 53 drawings.

\section{Findings and Discussion}

The findings of the research were dealt according to the three themes determined within content analysis.

1. Violence Topics

2. Features perpetrators and victims

3. Types of violence

\section{Violence Topics}

The most prevalent topic in the drawing was found to be violence from an adult to an adult, that is, 32 themes. The other topics in order of prevalence were violence from a child to a child (12 themes), domestic violence ( 9 themes), war ( 3 themes), violence from an adult to an animal ( 3 themes), violence from an adult to a child (3 themes), terrorism ( 2 themes) and violence from a man to woman (1 theme). 


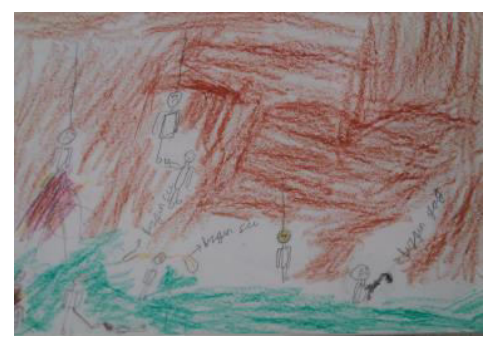

Drawing $1(\mathrm{M} ; 9)$

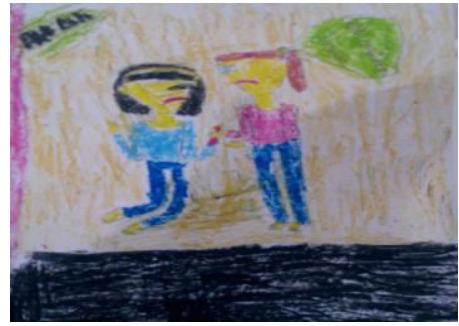

Drawing $2(\mathrm{~F} ; 10)$

In drawing 1, violence from an adult to an adult was drawn. The people were portrayed as were hanged with a rope from their necks and they were exposed to violence with boiling oil or water. The explanation of the student who drew this picture was that the people were burned and persecuted.

Drawing 2 is an example for a drawing showing violence from a child to a child. The explanation of the student who drew this picture was that his neighbor's daughter at 5 th grade always beats her sister at 2 nd grade.

If the parents behave each other in an aggressive manner and are the children think that the problems can be solved by aggressive behaviors, they regard aggression as a way of solving problems. These children see aggressive manners as part of life and they begin to practice this manner in their lives Kağıtçıbaşı (1999) (trans. Özmen, 2004). From this point of view, parents or other adults must not forget that they are role models for their children. Regarding the violence from a child to a child, from some social learning theories and the first levels of socialization, the children learn how to behave by observing and imitating their environment. So, the second common type of violence is the violence from a child to a child. Migration, inability in adapting to a new environment, lack of leisure time activities and unemployment can be the factors for violence.

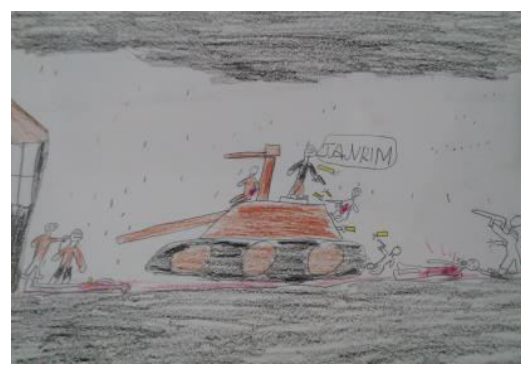

Drawing $3(\mathrm{M} ; 10)$

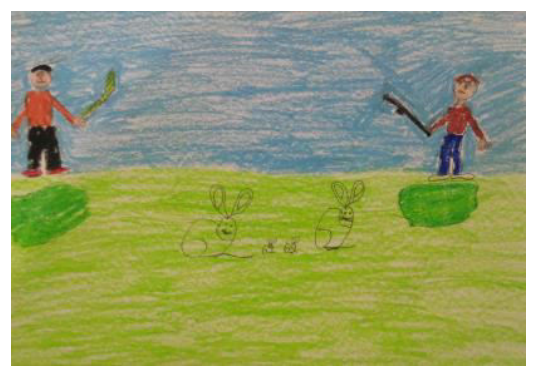

Drawing 4 (F;9) 
Drawing 3 is a drawing about war. The explanation of the student who drew this Picture was that he drew the last violent scene of the film Fury.

Violence, as a learned behavior, may be commented as being internalized by children via TV which is much more effective than the family and school in shaping the social values. Moreover, it can also be stated that watching violent scenes on TV is an important way of learning violence as in this drawing.

The study of Özgür, Yörükoğlu ve Arabacı (2011) supports our research. In their study, the fact that a great number of the children learn violence from printed/visual media is an important finding $(72.8 \%)$.

This may be the result of the frequency of the news including violence in printed and visual media. Another factor is that for the fear of low ratings, the news is presented in a tendency of using violence.

Picture 4 is a drawing showing violence from an adult to an animal. The explanation of the female student who drew this Picture was that two hunters want to kill the rabbit family. Here, it can be inferred that violence to an animal may be experiencing violence, pain and fear.

\section{Features perpetrators and victims}

In the drawings, it was seen that 35 men, 8 women, 5 girls and 1 boy used violence whereas 25 men, 13 women, 4 girls, 1 boy and 3 animals were exposed to violence.

In drawing 5, an adult beating another adult were portrayed. Some blood trails are seen on the face and body of the adult who was exposed to violence. There is a stick in the hand of the adult who used violence. The students who drew the drawing said that the adult who used violence "beat and beat" the other one.

In drawing 6, the girl who drew wrote at the back of the paper that a man killed his wife. When this drawing is examined in detail, it is seen that the man has a knife in his hand there are some blood trails on woman's body. As in the drawings 5 and 6, the parents and other adults such as the teachers and relatives cause the individual to develop weak inner conscience and moral. Moreover, the individual will be aggressive, anxious and angry to everyone around him and he will assume that by using violence, he will be able to solve all the problems in social life. 


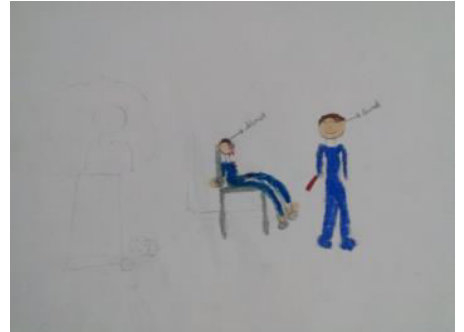

Drawing 5 (F;10)

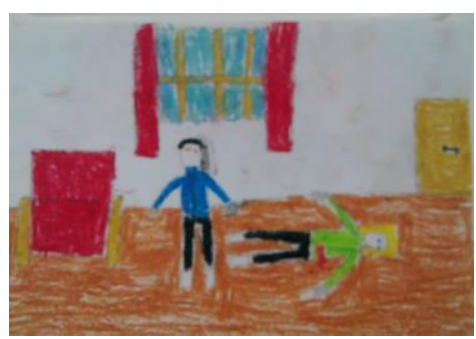

Drawing $6(\mathrm{M} ; 10)$

There are some blood trails on the bodies of the people in Drawing 3. There are guns in the hands of the people who use violence. The children's beating each other, the rise in the number of the incidents resulting with death or physical injuries is the things we hear frequently. The heroes who reach their aim by using violence are seen as the identification elements by children.

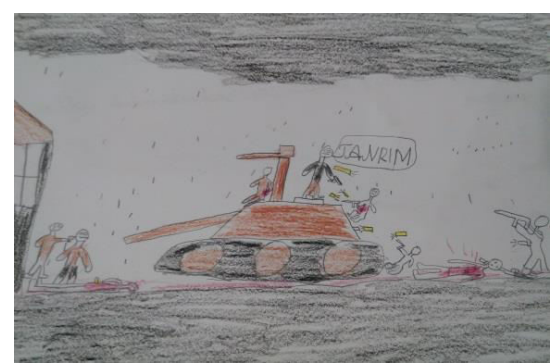

Drawing $3(\mathrm{M} ; 10)$

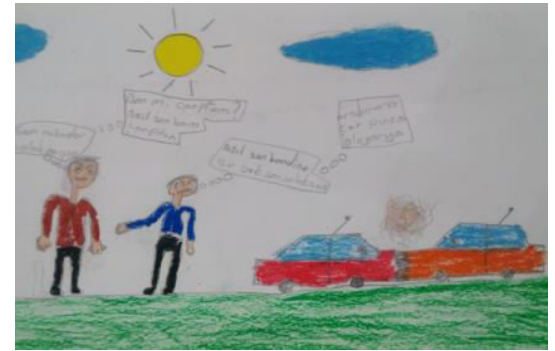

Drawing $7(\mathrm{~F} ; 10)$

With their drawings (Drawing 3), the students put down the fact that they are easily affected by the TV series and cartoons. This fact reveals that media has a big impact on the children's violence mentality. The drawings also shows that the children are aware that media has some negative effects on them. When drawing 7 and 8 are examined, it is seen that some students use speech bubbles to support and strengthen the conversation. In some drawings, angry faces strengthen the theme.

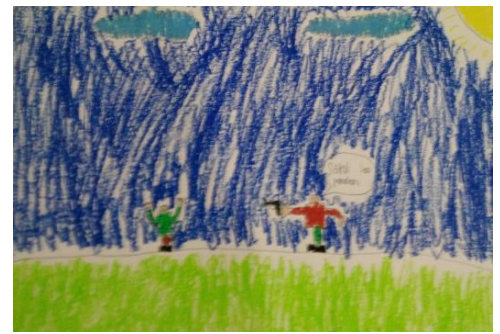

Drawing 8 (M;9) 
When the news regarding verbal violence is analyzed, the behaviors such as threatening, insulting, and humiliation come to the forefront (Teyfur, 2014).

\section{Types of Violence}

In these drawings, as the forms of the use of violence, using guns (18), beating (16), using stab tools (10), beating with a stick (7), burning (3), tearing hair and some verbal ways of violence are portrayed. It is found that the type of violence for giving physical harm was used mostly as a result of physical violence's being the most common and visible type of violence in the society.

In Drawing 9, there are two adults using violence against an animal with a stick and a stab tool. The girl who drew this Picture took a note as "interfering one's eating" on the back of the paper. In Drawing 10, the girl wrote "The cruelty of the Germans against Jewish people". There are hand chains, and the users of the violence have some sticks in their hands. There is an oven in which the people were born on the right top of the Picture.

In their research, Özkan ve Çifci (2010) found that the $32.9 \%$ of 295 students were exposed to physical violence. Baş ve Kabasakal (2010) told that the mostly seen type of violence among the students is physical fighting. Çubukçu ve Dönmez (2012) revealed that the types of violence at school are fighting, threatening and swearing. Teyfur (2014), in his research, showed that the stabbings at school has reached from $1,49 \%$ to 4,23 , which is parallel with our results.

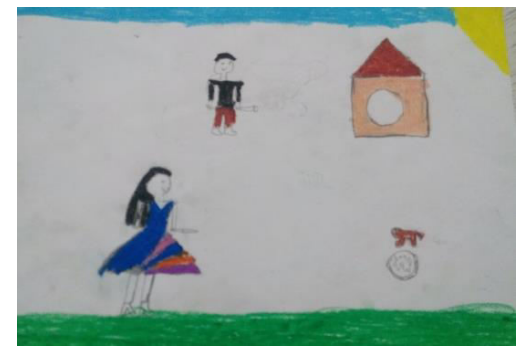

Drawing $9(\mathrm{~F} ; 9)$

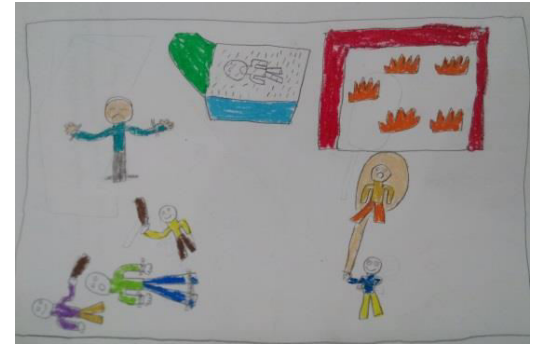

Drawing $10(\mathrm{~F} ; 10)$

In the drawings, it is understood that an individual who has a physical power resorts to violence to make control, show strength and make pressure on the one who is less powerful. There is aggression and anger on the basis of violence. Individuals who completed their development in healthy social environment generates healthy societies and at this point, it can be thought that is there is an adequacy, this situation will cause an act of violence. 


\section{Discussion and Conclusion}

In our research on the perceptions of violence on primary school students of 9-11 years old, the findings refer to several important points.

Our study shows that according to the violence perceptions of students, the most common type of violence is physical violence from an adult to an adult. Mostly men use violence and the ones who are exposed to violence are men, women and children respectively. This finding is similar to the other researches in the fields.

In their drawing study, Akbulut and Saban (2012) studied with 80 students of 9-11 years old and found out that the most common type of violence is physical violence at home. Moreover, they portrayed that the user of the violence is the father and the one who is mostly exposed to violence is the son and the mother. Özkan ve Çifci (2010) showed that the $32.9 \%$ of 295 students were exposed to physical violence. In the same study, it was shown that men resort to violence mostly.

The factors of the determiners of violence were found as the unemployment of men, the irregular employment of men and the regular use of alcohol Dönmez, Şimşek ve Günay (2012). The cause of the high rate of physical violence is that this type of violence is very common in society. Physical violence, as one of the types of the violence and the most drawn type of violence in our research, is a tool for pressure on youngsters and women and the most common way of supremacy.

In our study, according to the sex variable, the act of violence is used mostly by men. The similar findings are seen in the studies of Özkan ve Çifci, 2010; Kapıkıran ve Fiyakalı 2003. Yurtal ve Cenkseven (2007) found out that the male and elder students use more violence at school.

İbilioğlu's study (2012) reveals that despite the fact that both men and women are exposed to violence, the victims are mostly women and children. For the studies of Lee, Baillargeon, Vermunt, Wu, \& Tremblay (2007) (transf. Baş ve Kabasakal, 2010), the socialization process makes pressure on men and women on acquiring the behaviors such as men or women. This situation encourages girls in the solution of problems about the conflicts to have more empathetic and pro social behaviors.

The fact that the users of violence are mostly men gives us information about the patriarchal family structure of our society. Especially the destructive behaviors of men in solving problems are perceived as a sign of masculinity.

The results of the study show that the children are aware of the acts of violence around them. Drawing is an important tool for understanding the situations of 
children who cannot express themselves verbally. But drawing is not the only way to achieve this goal.

The drawings of the children can be used by their class teachers or mentors. The students who are doing master's or $\mathrm{PhD}$ degrees can do these kinds of researches. However, in order to arrive at a decision, some other methods other than drawing must be used.

The children witness violence in their family, at school, between their friends or from media. For the healthy mental development of a child, it is important that the environment that a child lives must be isolated from violence. Moreover, the society needs to be educated that violence has many negative and harmful effects on children. Despite not being directly exposed to violence, being a witness to violence can sometimes means being exposed to violence.

When the results of the study are taken into account, families, teachers and media have significant duties in developing the children. In order to decrease the negative effects of media, a mechanism for the control of media can be used. The children can consult to their families when they choose friends and this can prevent the children from gaining harmful behaviors.

It is hard to make a generalization on a qualitative study. One of the obstacles for this generalization is the nature of social acts. Social acts are not stable, they gradually change. Even for making finite generalizations, the changing nature of the social acts and the impossibility of creating the same environment for the second time must be taken into account.

This study was structured by the drawings of children. After this step, different methods and techniques and a broader sample of participants can be used for identifying children. The perceptions of children on different subjects can be evaluated by drawing technique. As the number of the participants is low, there can be some absences for generalization. Moreover, the study can be conducted to elder and different age groups. Some other studies on violence can be applied to families, schools and teachers. The new studies will have contribution to literature. 


\section{References and notes:}

Akbulut, M.G. ve Saban, A. (2012). İlköğretim Öğrencilerinin Şiddetle İlgili Algılarının Çizdikleri Resimler Aracılığıyla İncelenmesi. Turkish Journal of Education, 1(1).

Arıc1, B. (2006). Resim, Psikoloji ve Çocuğun Dünyasında Resim. Atatürk Üniversitesi Güzel Sanatlar Fakültesi Dergisi, 10.

Artut, K. (2004). Okul Öncesi Resim Eğitiminde Çocukların Çizgisel Gelişim Düzeylerine İlişkin Bir İnceleme. Çukurova Üniversitesi Sosyal Bilimler Enstitüsü Dergisi, 13(1).

Ayan, S. (2006). Şiddet ve Fanatizm. C. ̈. İktisadi ve İdari Bilimler Dergisi, 7(2).

Ayan, S. (2007). Aile İçinde Şiddete Uğrayan Çocukların Saldırganlık Eğilimleri. Anatolian Journal of Psychiatry, 8, 206-214.

Baş, Uz, A. ve Kabasakal, Topçu, Z. (2010). İlköğretim Okullarında Saldırganlık ve Şiddet Davranışlarının Yaygınlığı. İlkögretim Online, 9(1), 93-105.

Çubukçu, Z. ve Dönmez, A. (2012). İlköğretim Okullarında Görev Yapan Öğretmenlerin Okuldaki Şiddet Üzerine Görüşleri. Elektronik Sosyal Bilimler Dergisi, 11(40). Taken from:http://dergipark.ulakbim.gov.tr/esosder/article/view/5000068493

Damanhouri, Miramar (2018), The advantages and disadvantages of body language in Intercultural communication .Khazar Journal of Humanities and Social Sciences, Baku, Azerbaijan, Volume 21 № 1 2018, pp.68-82

Deveci, H., Karadağ, R. ve Yılmaz, F. (2008). İlköğretim Öğrencilerinin Şiddet Algıları, Elektronik Sosyal Bilimler Dergisi, 7(24). Taken from: http://dergipark.ulakbim.gov.tr/esosder/article/view/5000068163

Dönmez, G., Şimşek, H. ve Günay, T. (2012). Evli Erkeklerde Eşlerine Yönelik Şiddet ve İlişkili Etmenler. Türkiye Halk Sa ̆̆lı̆̆ Dergisi, 10(3).

Durualp, E., Çiçenoğlu, S., Mümünoğlu, S., Kalkanlı, G. ve Altuntaş, Z. (2012). Hastanede Yatmış Olan Okul Öncesi Dönem Çocuklarının Yaptıkları Resimlerinin İncelenmesi. Ĕ̈itim Öğretim Araştırmaları Dergisi, 1(3).

Güleç, H.,Topaloğlu, M., Ünsal, D. ve Altıntaş, M. (2012). Bir Kısır Döngü Olarak Şiddet.Psikiyatride Güncel Yaklaşımlar, 4(1), 112-137.

Gürsu, O. (2015). Sanat ve Psikoloji Etkileşimi: Geleneksel Türk-İslam Sanatları Merkezli Bir Okuma Denemesi. Uluslar arası Sosyal Araştırmalar Dergisi, 8(38).

Hiçyılmaz, Y., İnci, M.A ve Seven, S. (2015). 7-10 Yaş Grubu Çocukların Şiddet Algılarının Resimler Aracılığıyla Sosyal Güçler Bağlamında İncelenmesi. International Periodical for the Languages, Literature and History of Turkish or Turkic, 10(15), 503-518.

İbilioğlu, A. O. (2012). Aile İçi Şiddet. Psikiyatride Güncel Yaklaşımlar, 4(2), 204-222.

Kapıkıran Acun, N. ve Fiyakalı, C. (2003), Lise Öğrencilerinde Akran Baskısı ve Problem Çözme. Pamukkale Üniversitesi Eğitim Fakültesi Dergisi.

Kar, Ö. ve Toros, F. (2015). Aile İçi Şiddet ve Çocuk İstismarı Olgularında Sanat Terapisi. Hacettepe University Faculty of Health Sciences Journal. 1(2).

Keskin. Paktuna, S. (2010). Çocuk Çizgilerindeki Giz. Çöp Çocuk. Boyut Matbaacılık.

Kocacık, F. (2001) Şiddet Olgusu Üzerine. C. Ü İktisadi ve İdari Bilimler Dergisi, 2(1).

MEB (2008).Öğrencilerin Şiddet Algısı. Eğitimi Araştırma ve Geliştirme Dairesi Başkanlığ 1 , Ankara.

Mülayim, Selçuk. (2000). Sanat ve Şiddet. Taken from: http://mimoza.marmara.edu.tr/ avni/dersbelgeligi/kunduz/siddet/sanat ve şiddet.htm 
Ötgün, C. (2008). Sanatın Şiddeti ve Sınırları. Gazi Üniversitesi Güzel Sanatlar Fakültesi Sanat ve Tasartm Dergisi, 1.

Özgür, G., Yörükoğlu, G., Ve Arabac1, B. (2011). Lise Öğrencilerinin Şiddet Algıları, Şiddet Eğilim Düzeyleri ve Etkileyen Faktörler. Journal of Psychiatric Nursing, 2(2), 53-60.

Özkan, Y. ve Çifci Gökçearslan, E. (2010). Düşük Sosyo-Ekonomik Düzeydeki İlköğretim

Okullarında Akran Zorbalığı. Illkögrreti Ĕgitim Online 9(2), 576-586.

http://ilkogretimonline.org.tr/vol9say2.html adresinden alınd1.

Özmen, Kaymak, S. (2004). Aile İçinde Öfke ve Saldırganlığın Yansımaları. Ankara Üniversitesi Ĕ̈itim Bilimleri Fakültesi Dergisi. 37(2), 27-39.

Page, A. Z. ve İnce, M. (2008). Aile İçi Şiddet Konusunda Bir Derleme. Türk Psikoloji Yazllarl, 11(22), 81-94.

Sadık, F., Çakan, H. ve Artut, K. (2011). Çocuk Resimlerine Yansıyan Çevre Sorunlarının Sosyo-Ekonomik Farklılıklara Göre Analizi. İlköğretim Online, 10 (3), 1066-10880. Taken from: http://dergipark.ulakbim.gov.tr/ilkonline/article/view/5000037930/5000036788

Savaş, İ. (2014). Çocuk Resmi ve Bilinçaltı. İstanbul Arel Üniversitesi, Sosyal Bilimler Enstitüsü,Yüksek Lisans Tezi.

Şenol, D. ve Mazman, İ. (2014). Çocuğa Uygulanan Şiddet: Türkiye Özelinde Sosyolojik Bir Yaklaşım. KMÜ Sosyal ve Ekonomik Araştırmalar Dergisi, 16 (26), 11-17

Teyfur, M. (2014). Basında Yer Alan Okullarda Şiddet İle İlgili Olayların Değerlendirilmesi. Ilkögretim Online, 13(4), 1331-1330. Taken from this link: http://dergipark.ulakbim.gov.tr/ilkonline/article/view/5000075277

Yavuzer, H. (2009). Resimleriyle Çocuk (13). İstanbul: Remzi Kitabevi.

Yıldırım, A. ve Şimşek, H. (2013). Sosyal Bilimlerde Nitel Araştırma Yöntemleri (6). Ankara: Seçkin Yayıncılık.

Yıldız, Armağan, S. (2012). İlköğretim Birinci Kademe Öğrencilerinde Okul Kavramına İlişkin Nitel Bir Analiz. Kuram ve Uygulamada Eğitim Bilimleri, 12(2), 609-626.

Yılmaz, M. (2013). Bedenin Gösterisinde Yanılsamadan Gerçek Şiddete-Sanatta Kanlı İçselleştirmeler. İdil, 2 (10).

Yurtal, F. ve Cenkseven, F. (2007). İlköğretim Okullarında Zorbalığın Yaygınlığı ve Doğası. Türk Psikolojik Danışma ve Rehberlik Dergisi, 3(28).

Zorlu, Y. (2016). Medyadaki Şiddet ve Etkiler. Humanities Sciences, 11(1). 13-32. 


\title{
Summary
}

\section{9-11 Year Old Students' Perception of Violence Reflected in Their Drawings}

\author{
Melih Burak Ozdemir \\ Research Center of Counselling, Samsun,Turkey
}

Senem Gurkan

Ondokuz Mayıs University, Samsun,Turkey

Yashar Barut

Ondokuz Mayıs University, Samsun,Turkey

Violence, which can be defined as any threat towards the physical and psychological integrity of a human being, can result in fear, anxiety and severe behavior problems on children, whether exposed or witnessed. In this study, it is planned to achieve children's perception of violence expressed by drawing and obtaining data in this way. In this study, the type of violence children portray in their drawings, how they determine to portray characteristics who perpetrate violence and are exposed to it as well as how is applied are analyzed. To measure how children perceive the violence, they were asked to draw a picture describing the ones who use violence and the ones who are exposed to violence. The pictures, drawn by children who participated in the study, were examined from a semantic perspective and content analysis method was adopted on the pictures. The research was conducted in Samsun province in the middle socio-economic level, with total of 53 students, 27 girls and 26 boys between the ages of 9-11 who were randomly selected representing two schools. Drawings were examined according to the issues they portrayed and then, semantic and content analysis was applied. In the children's drawings, it is shown that the violence of adults is reflected more. These findings indicate that child to child violence, domestic violence, war, adult to child violence, adults to animal violence and terrorism is portrayed respectively. Generally, males are portrayed in the drawings.

Drawn illustrations show that children are aware of the growing violence in their environmental. Raising the children in nonviolent social environment seems important for their healthy development. We can say that drawing, which is a simple tool for exploring the children's inner world, can be used by all professionals responsible for children education.

Keywords: Violence, drawing, primary school, terrorism, education 